Dorota Zdunkiewicz-Jedynak

DOI: 10.33896/PorJ.2021.4.5

(Uniwersytet Warszawski,

e-mail: d.jedynak@uw.edu.pl)

ORCID: 0000-0002-4710-9826

\title{
INFORMACJA PRAGMATYCZNA W SLOWNIKU ORTOEPICZNYM. STAN OBECNY I POTRZEBY
}

\section{PRAGMATYKA - ROZUMIENIE POJĘCIA}

Termin pragmatyka najczęściej dziś jest wiązany $z$ mechanizmami rozumienia $i$ interpretowania wypowiedzi $z$ uwzględnieniem kontekstu, z „działaniem człowieka poprzez użycie środków językowych” [Kalisz 1993 , 9]. Piotr Stalmaszczyk nazywa to ujęcie pragmatyki prakseologicznym [Stalmaszczyk 2008, 17]. $Z$ takim rozumieniem pragmatyki oswoiliśmy się w lingwistyce pod wpływem teorii aktów mowy i teorii implikatur.

W kontekście pracy nad nową koncepcją słownika ortoepicznego stosowniejszy jednak wydaje się powrót do pierwotnego rozumienia pragmatyki (ujmowanej jako element triady: semantyka, składnia, pragmatyka). Pojawiło się - przypomnijmy - na gruncie logiki, w obrębie teorii semiotycznej. Jej autorem jest Charles Morris. Według amerykańskiego filozofa syntaktyka bada relacje składniowe zachodzacce pomiędzy znakami, semantyka zajmuje się relacją między znakami a obiektami, które są lub moga być denotowane przez znaki, pragmatyka zaś dotyczy relacji zachodzących pomiędzy znakami a ich interpretatorami [Morris 1938, 30; por. Stalmaszczyk 2008, 13].

Ujęcie semiotyczne zasadniczo jest również akceptowane na gruncie lingwistyki, stanowiło nawet źródło inspiracji wielu prac językoznawczych [por. np. Stalnaker 1970, 272-289; 1972; Montague 1968; 1974, 95-118; Gazdar 1979, 2]. Ten ostatni badacz pod koniec lat 70. XX w. zaproponowal, by pragmatykę wiązać $z$ takimi aspektami wypowiedzi, których nie można przedstawić, odwołując się do warunków prawdziwości [Gazdar 1979, 2; por. Stalmaszczyk 2008, 15].

Wśród współczesnych podejść do pragmatyki za najbardziej przydatne i inspirujące w kontekście nowoczesnego słownika ortoepicznego opartego na aktualnych rozwiazaniach metodologicznych i odpowiadajacego nowym wyzwaniom komunikacyjnym oraz dzisiejszym potrzebom użytkowników języka wydaja się propozycje rozumienia pragmatyki osadzone w praktyce leksykograficznej, w szczególności zaś pomysły Jurija Apresjana i Andrzeja Bogusławskiego. W koncepcjach obu badaczy punktem odniesienia terminu pragmatyka sa wy rażenia językowe, a nie - akty mowy. Obie propozycje w zakresie leksykograficznego rozróżnia- 
nia semantyki i pragmatyki powinny być wzięte pod uwagę we współczesnych leksykograficznych przedsięwzięciach ortoepicznych.

W ramach koncepcji całościowego opisu języka rosyjski językoznawca i leksykograf sformułował następującą definicję pragmatyki:

Terminem pragmatyka będziemy określać utrwalony w jednos tce językowej (w leksemie, afiksie, gramemie, konstrukcji składniowej) stosunek mówiącego:

(1) do rzeczywistości,

(2) do treści wypowiedzi,

(3) do adresata.

Należy podkreślić, że chodzi nam nie o ocenę dokonywaną przez mówiącego w wypowiedzi, lecz o ocenę zleksykalizowana lub zgramatykalizowana, która wbudowana jest bezpośrednio w plan treści jednostek językowych i ma w zwiąku z tym określony stały status w języku [Apresjan (1988) 2012, 42].

J. Apresjan, biorąc pod uwage pragmatyczny aspekt jednostki języka, pisał w innym miejscu:

Należy do niej szeroki krag zjawisk, poczynając od elementów ekspresywnych znaczenia (...), a kończąc na tych modalnych składnikach znaczenia (związanych nie $z$ opisywaną sytuacja, lecz z sytuacją komunikacji), które A. Wierzbicka opisywała jako ramę modalną wyrażenia, a Ch. Fillmore jako presupozycję [Apresjan (1974) 2000, 76].

Według J. Apresjana informacja pragmatyczna ma trzy cechy:

1) jest wyrażana językowymi środkami peryferyjnymi (w porównaniu ze środkami wyrażania informacji semantycznej; oznacza to na przykład, że w podstawowych znaczeniach wyrazów udział czystej semantyki jest większy niż w znaczeniach przenośnych czy frazeologicznie powiazanych);

2) dysponujemy różnymi środkami językowymi do jej przekazywania, tzn. brak możliwości jej lokalizacji w jakiejś jednej jednostce języka;

3) ściśle powiązana jest $z$ informacją semantyczną.

Główne typy informacji pragmatycznej to według rosyjskiego lingwisty [por. Apresjan (1988) 2012, 52-53]:

- kwalifikacja stylistyczna (także komponent oceniający),

- takie cechy leksemu jak performatywność lub inna nietypowa funkcja illokucyjna,

- status nadawcy i odbiorcy pod względem wieku, hierarchii społecznej lub innej,

- konotacje.

Oryginalna propozycje ujmowania pragmatycznych właściwości jednostek języka przedstawili również Andrzej Bogusławski i Jan Wawrzyńczyk [Bogusławski, Wawrzyńczyk 1993, zob. także wcześniej Bogusławski 1973, 121-151; Bogusławski, Garnysz-Kozłowska 1979, 301-326] oraz kontynuatorzy projektu Sondy słownikowej [por. Bogusławski, Danielewiczowa 2005]. Autorzy za pragmatyczne uznają cztery kategorie właściwości wyrażeń: 
- właściwości a k o m o d a cyj n e (zasięgu, relacyjne i sytuacyjne),

- właściwości emotywne,

- właściwości praktyczne,

- właściwości poetyckie.

Poszczególnym kategoriom odpowiadają w ujęciu autorów określone kwalifikatory pragmatyczne.

A k o m o d a cj a odpowiada wyborowi stylistycznemu. Zwiazana jest $z$ takimi właściwościami wyrażeń, które wynikają $z$ ich przystosowania do określonych zakresów (kręgów) użycia. Zakresy te istnieją niezależnie od intencji mówiącego [por. Bogusławski, Wawrzyńczyk 1993, 33]. Autorzy wyróżniaja 3 rodzaje tak rozumianej akomodacji (przystosowania):

- akomodacja zasięgu - o właściwościach zasięgu informuja takie kwalifikatory jak: środ. (wyrażenie o zasięgu ograniczonym do pewnego środowiska wskazanego jednak ogólnie), profesj. (wyrażenie o zasięgu ograniczonym do grupy zawodowej), nowe (wyrażenie świeżo lub relatywnie świeżo wprowadzone do użytku, nieposiadające ustabilizowanej „afiliacji” środowiskowej lub statusu powszechności), daw. (wyrażenie dawne, czyli używane przez przedstawicieli pokolenia nieżyjącego lub wygasającego), młodz. (wyrażenie młodzieżowe), dziec. (wyrażenie używane przez dzieci lub dorosłych zwracających się do dzieci) [zob. Bogusławski, Wawrzyńczyk 1993, 33-34];

- akomodacja relacyjna, gdy czynnikiem rozstrzygajacym o możliwości wyboru jednostki sa towarzysko-społeczne relacje między nadawca a odbiorca wypowiedzi (jak hierarchiczność, stopień zażyłości), nadawca a słuchaczem niebędącym bezpośrednim odbiorca (adresatem wypowiedzi) oraz relacja między nadawca a bohaterem wypowiedzi [por. Huszcza 2006, 47); właściwościom relacyjnym autorzy przyporzadkowali takie kwalifikatory jak: famil. (wyrażenie familiarne, stosowane w relacjach swobodnych i intymnych), antyfamil. (wyrażenie antyfamiliarne), humil. (wyrażenie humilizacyjne, pokornościowe), oględ. (wyrażenie oględne służące stonowaniu wypowiedzi), godn. (wyrażenie godnościowe) [zob. Bogusławski, Wawrzyńczyk 1993, 34];

- akomodacja sytuacyjna, gdy czynnikiem ograniczajacym użycie jednostki jest typ sytuacji mownej, odpowiadajacy kręgom życia społecznego; ze względu na akomodację sytuacyjna wyrażeniom przypisywane sa tzw. rejestry stylistyczne - odpowiadaja im takie kwalifikatory jak: urocz. (wyrażenie uroczyste), urzęd. (wyrażenie urzędowe), oficj. (wyrażenie oficjalne), ksiażk. (wyrażenie książkowe), public. (wyrażenie publicystyczne), pot. (wyrażenie potoczne), posp. (wyrażenie pospolite, czyli takie, którego użycie narusza savoir vivre), ordyn. (wyrażenie ordynarne, mogace stanowić obrazę), eufem. (wyrażenie eufemistyczne, używane zamiast wyrażenia tabu), nieeufem. (wyrażenie nieeufemistyczne, czyli takie, na który nałożony jest zakaz tabuistyczny) [zob. Bogusławski, Wawrzyńczyk 1993, 34]. 
E m o tyw n oś ć w ujęciu A. Bogusławskiego i J. Wawrzyńczyka jest właściwościa wyrażeń pozwalająca na wprowadzenie odbiorcy w określony stan emocjonalny. Na tę kategorię składaja się kwalifikatory: pieszcz. (wyrażenie pieszczotliwe), rub. (wyrażenie rubaszne), niegrz. (wyrażenie niegrzeczne), lekcew. (wyrażenie lekceważące), pogard. (wyrażenie pogardliwe), piętn. (wyrażenie piętnujace), eufor. (wyrażenie euforyczne, wprowadzające nastrój radosnego podniecenia), minor. (wyrażenie minorowe, wprowadzające nastrój depresyjny, rozczarowania, goryczy) [zob. Bogusławski, Wawrzyńczyk 1993, 34].

Właściwości praktyczne wyrażeń wreszcie sa wyznaczane przez zachowanie się odbiorcy i/lub nadawcy w ich działaniach pozapoznawczych. Właściwościom tym odpowiadają w ujęciu A. Bogusławskiego 3 kwalifikatory: perform. (wyrażenie performatywne), quasi-perform. (wyrażenie quasi-performatywne - towarzyszy rzekomemu magicznemu stwarzaniu stanu rzeczy), behab. (wyrażenie behabitywne - gdy wyrażenie towarzyszy zachowaniom symbolicznym, niemajacym funkcji reprezentatywnej, takim jak powitania, pożegnania, odzywki karciane itp.) [zob. Bogusławski, Wawrzyńczyk 1993, 34].

Właściwości poetyckie dla odmiany wprowadzaja do wypowiedzi efekty ludyczne i zdobnicze. Kategoria obejmuje 8 kwalifikatorów: rytmiz. (wyrażenie rytmizowane), wyszuk. (wyrażenie wyszukane), arch. (wyrażenie archaizujące), obr. (wyrażenie obrazowe), żart. (wyrażenie żartobliwe), iron. (wyrażenie ironizujące), litota (wyrażenie łagodzace), peryfr. (wyrażenie peryfrastyczne).

\section{INFORMACJA PRAGMATYCZNA W WSPP}

Przegląd ostatniego, najbardziej wśród użytkowników języka znanego słownika ortoepicznego - Wielkiego słownika poprawnej polszczyzny pod redakcją Andrzeja Markowskiego [Markowski (red.) 2018] - uwzględniający przedstawiony w leksykonie rejestr kwalifikatorów oraz częstość ich rzeczywistego zastosowania w opisach haseł pozwala stwierdzić, że $\mathrm{w}$ tym słowniku informacja pragmatyczna odnosi się przede wszystkim do normy w zakresie akomodacji zasięgu środowiskowego (np. rejestr tego typu kwalifikatorów jest najliczniej reprezentowany, np. aktor., bud., dzien., farm., rad., środ., socjol., techn., teatr., uczn., filoz., fiz., górn., kośc., łow., młodz., mor., muz., nark., naucz., rel., żołn., żegl., daw., przestarz., hist.), poszerzonej tu o zas ięg te ry torialny (np. reg., st., warm., wielkopol., wsch., zach., białost., ciesz., gw., krak., podh., lwow., małop., maz., pd.), dalej akomodacji sytuacyjnej (np. posp., pot., erud., eufem., ksiażk., nauk., oficj., publ., urzędow.), wreszcie właściwości e motywnych (opisuja tę właściwość jednostek takie kwalifikatory jak: ekspr., lekc., obraźl., obelż., pieszczot., pogard., żart.). W stopniu o wiele mniejszym reprezentowana jest w tym 
słowniku informacja normatywna dotyczacca a ko mo dacji rela cyjn ej (opisywanej bodaj tylko przez kwalifikator pouf.) i wła ściw oś ci p o e tyckie (odpowiednio sygnalizowane kwalifikatorami iron., żart.). W tym słowniku informacja pragmatyczna ma zreszta - jak się zdaje - charakter drugoplanowy, a może lepiej powiedzieć: służebny - jest konsekwencja przyjętej w tym słowniku koncepcji normy dwupoziomowej (wzorcowej i użytkowej), dlatego kwalifikator stylistyczny pot. nierzadko jest sprzęgnięty z kwalifikatorem normatywnym potocznie dopuszczalne. Ponadto zasadniczym przedmiotem kodyfikacji normy językowej w tym opracowaniu są właściwości ściśle semantyczne i gramatyczne opisywanych jednostek, a nie ich wartość pragmatyczna, tak jakby w praktyce użytkowników języka ta sfera własności jednostek języka nie podlegała społecznej normalizacji.

Przy okazji: niejasny jest status kwalifikatorów lepsze (lepiej) i gorsze (gorzej) - w nowoczesnym słowniku opartym na badaniach korpusowych i statystycznych należałoby $z$ nich zrezygnować - ich stosowanie w WSPP nosi wyraźne znamiona subiektywizmu. Ocena redaktorów w słowniku normatywnym na miarę XXI wieku powinna być „wchłonięta” przez jakiś kwalifikator obiektywizujący odwołujący się do pragmatycznego czynnika autorytetu kwestion. ( $\mathrm{z}$ uzupełnieniem: ze względu na...).

\section{KOMPONENT PRAGMATYCZNY W ŚWIADOMOŚCI UŻYTKOWNIKÓW JĘZYKA}

Korespondencja internetowych poradni językowych pokazuje, że wiele $z$ zadawanych przez użytkowników języka pytań dotyczy takich aspektów posługiwania się jednostkami języka, które mają charakter czysto pragmatyczny - i to w sensie znacznie szerszym niż tylko akomodacja stylistyczna:

Witam, czy na spotkaniu firmowym, przedstawiajac szefową firmy, bard zi ej po p r aw n i e będzie powiedzieć: „A teraz przedstawiam go s pody nię dzisiejszego spotkania, panią Annę Kowalska", czy też należy użyć słowa go s podarz?

Szanowni Państwo, ostatnio byłem świadkiem sytuacji, w której student zwrócił się do pani profesor: Czy jest dziś na wydziale pani maż?. Chodzi oczywiście o to, że mąż pani profesor również pracuje na uczelni. Wobec różnicy w hierarchii ja bym na jego miejscu zapytał neutralnie o pana profesora X. W moim odczuciu taka wypowiedź jak jego niejako eksponuje sytuację prywatna osoby wyżej usytuowanej, co odbieram jako nietaktowne. Ale może jestem przewrażliwiony, dlatego proszę o opinię.

Szanowni Państwo, mój syn jest ateista, i w związku z tym nie uczęszcza na zdjęciach $z$ religii. W szkole zwrócono mu uwagę że niepoprawnie wita (dzień dobry) oraz tytułuje (per pan) księdza. Jak poprawnie powinien zwracać się do księdza ateista?

Czy mówienie (pisanie) o siedemdziesięcioletniej obcej kobiecie babcia, a o mężczyźnie dziadek jest zgodne $z$ polską etykietą językową? 
Jak będzie p o praw ni e: zaproponować osobę Jana Nowaka czy zaproponować osobe pana Jana Nowaka?

Szanowni Państwo, chciałabym zapytać, czy w pewnych sytuacjach mo ż n a u z n ać za dopuszczalny zwrot Szanowna Pani Anno? Pytanie dotyczy sytuacji, gdy zwracam się do kogoś, kogo dobrze znam, ale kto znajduje się wyżej w hierarchii. Oczywiście jeśli ta osoba ma jakiś tytuł lub zajmuje jakieś stanowisko, to piszę: Pani Doktor / Dyrektor, sa jednak sytuacje, gdy nie ma takiej możliwości, a Szanowna Pani wydaje się zbyt formalne.

Politycy używają sformułowania Pan Prezydent. Gdy prezydentem jakiegoś kraju jest kobieta (np. do niedawna Pani Prezydent Republiki Korei Park Geun-hye) sformułowanie Pani Prezydent jest trafne, gdyż oprócz wyrazu szacunku i podkreślenia stanowiska (Prezydent) wiadomo jest że Prezydent jest kobietą (Pani). Czy słowo Pan przed słowem Prezydent jest pleonazmem? Przecież sama forma (Prezydent) wskazuje na mężczyznę. Rozumiem, że w wołaczu lepiej dodać słowo pan [https://sjp.pwn.pl/poradnia; dostęp: 12.10. 2020].

Dla korespondentów poradni językowych (a zapewne - w ogóle dla zwykłych użytkowników języka niespecjalistów) język stanowi pewne kontinuum, w którym granica między semantyką a pragmatyką ma charakter rozmyty, a zjawiska $z$ obu płaszczyzn w naturalny sposób odnoszone są do pojęcia normy językowej, na której przestrzeganiu użytkownikom zależy w tym samym stopniu w odniesieniu do sfery semantycznej jak pragmatycznej - wszak w obu wypadkach pytaja o p o p raw ność.

Zgłaszane przez nich problemy pokazuja, że w świadomości użytkowników języka w ła ś c i w e użycie jednostek językowych nie ogranicza się do pozostawania w zgodzie $z$ regułami gramatyki czy respektowania sensu stricto $\mathrm{z} n$ a c $z$ e $n$ i a jednostek. Stanowi o nim również adekwatny pragmatycznie ich wybór spośród dostępnych środków języka - taki odpowiedni wybór jest pochodna znajomości ich właściwości wynikających $z$ określonych akceptowalnych zakresów ich użycia - istniejących niezależnie od intencji mówiącego, a także świadomość, co w praktyce za pomoca tych środków można osiagać. Chodzi tu więc zarówno o uwzględniane dotąd $\mathrm{w}$ tradycji ortoepicznej w największym stopniu przystosowania s y tu a cyj n e (społeczny typ sytuacji mownej odpowiadający kręgom życia społecznego) i przystosowania ś rod ow is kow e (np. w grupach zawodowych czy osób połączonych wspólnym hobby), jak i dotąd zwykle pomijane - ograniczenia r ela cyj n e (gdy istotne sa zwiazki, relacje między nadawca a odbiorcami, w tym kwestie zwiazane $z$ grzecznościa albo etyka słowa) czy właściwości praktyc zne. Z punktu widzenia leksykografa (ale i z perspektywy użytkownika słownika ortoepicznego) takie informacje sa dla komunikacji ważne. Sygnalizują bowiem ważne praktyczne konsekwencje użycia w tekście określonej jednostki językowej, wyboru tego, a nie innego wyrazu spośród środków oferowanych przez język. 


\section{INFORMACJA PRAGMATYCZNA W SEOWNIKU POPRAWNOŚCIOWYM A ROZUMIENIE KULTURY JĘZYKA}

Za wprowadzaniem w słowniku ortoepicznym w szerszym niż dotąd zakresie informacji pragmatycznej przemawiaja $i$ inne argumenty - chodzi o pewną filozofię uprawiania kultury języka, której wyrazem sa słowniki poprawnościowe, oraz o uwzględnienie bieżacych potrzeb komunikacyjnych native speakerów. Od lat 80. XX w. część językoznawców (przede wszystkim Jadwiga Puzynina) apelowała, by działania kulturalnojęzykowe kształtowały wrażliwość na użycia języka nie tylko niepoprawne, lecz także niewłaściwe pod względem pragmatycznym [por. np. Markowski, Puzynina 1993].

Osiagnięta po 1989 roku wolność słowa pozwalająca nam na nieskrępowane wyrażanie indywidualnych opinii, pluralizm życia publicznego maja nie tylko zalety, są także w dyskursie publicznym źródłem nadużyć, takich jak narastająca b ru ta li z a cj a zachowań językowych objawiająca się m.in. wulgary za cją czy obecnościa w dyskursie publicznym wyrażeń o b r aźli w y c h; wykluczająca mowa n i e n a w i ś c i, prowadzaca dziś do licznych procesów sądowych o zniesławienie. Rozwój nowych mediów, zwłaszcza dającego poczucie anonimowości i powszechnie dostępnego Internetu, otwiera drogę dla nieznanych w XX wieku, gdy powstawały 3 wielkie opracowania ortoepiczne [Szober 1937; 1948; Doroszewski (red.) 1976; Markowski (red.) 2012], zachowań językowych niewłaściwych, jak hejt czy trollowanie. Język polityki sięgający po słownictwo emocjonalne, a przede wszystkim semantycznie nieprecyzyjne, coraz częściej nie tylko uniemożliwia społeczne porozumienie, lecz blokuje nawet szansę na jakąkolwiek dyskusję. Wyraźnie dziś zatem widać, że niewłaściwe użycia języka nie ograniczaja się obecnie do niepoprawności gramatycznej i semantycznej.

Inny badacz - Mirosław Bańko - już ponad dekadę temu postulował, by kodyfikując normę językowa, zaakceptować wstępnie założenie, że ocena poprawności (rozumianej najogólniej jako społeczna akceptowalność) faktów językowych rzadko może być arbitralnie zero-jedynkowa. Norma językowa w ujęciu warszawskiego leksykografa obejmuje

sferę praktyki i zewnętrznych nakazów, ewentualnie uzupełniona o świadomość językową mówiących i ma charakter w i e lo p u n k t o w y, ponieważ uwzględnia ona różne punkty widzenia [Bańko 2008, 13].

\section{Bańko pisał:}

Tak jak norma wielopoziomowa, postulowana przez Kurkowska i wdrożona w NSPP, odbiera (...) ona ocenie faktów językowych charakter absolutny. O ile jednak norma wielopoziomowa relatywizuje oceny [tylko - D.J.] do sytuacji komunikacyjnych i do odmian języka (pozostając przy tym pod silnym wpływem tradycji), o tyle norma wielopunktowa uzależnia je od in ny ch okoliczności [pokreślenia D.J.]. 
Jeśli akceptuje się normę wielopunktową, za podstawę ocen normatywnych w języku można przyjąć powszechny zwyczaj albo świadomość językową mówiących, albo zewnętrzny wobec nich system zakazów i nakazów - albo wreszcie dowolną konfigurację tych czynników [tamże].

Wymieniane przez M. Bańkę czynniki mają, jak się wydaje, w większości status pragmatyczny. Przyjmując tę inspirująca koncepcję normy zaproponowana przez warszawskiego leksykografa, można sobie wyobrazić w słowniku takie pragmatyczne ze swej natury informacje o jednostkach języka, które dostarczałyby korzystającym ze słownika użytecznego i jak najobszerniejszego komentarza, w jakich okolicznościach użycie jednostki języka może być przez native speakerów lub ich część odbierane np. jako niegrzeczne, obraźliwe, deprecjonujące rozmówcę lub obiekt czy osobę, której wypowiedź dotyczy, kiedy może prowadzić do zakłóceń porozumienia między nadawca a odbiorca albo $z$ powodu ograniczonego zasięgu społecznego lub terytorialnego, albo z powodu tego, że jednostka językowa jest różnoznaczna (różnie rozumiana, semantycznie nieprecyzyjna, a nie wieloznaczna - tak jest np. w odniesieniu do wyrazów nazywających wartości). O problemie pisała i mówiła wielokrotnie Jadwiga Puzynina:

Kłopot (...) polega na tym, że granice języka wartości nawet w obrębie jednej kultury nie sa wyraźnie określone, są odmienne w ujęciu różnych osób (...). Na przykład słowo brat (w znaczeniu 'członek rodziny') dla jednych $z$ nas jest nacechowane pozytywnie, dla innych jest neutralne aksjologicznie. Podobnie jest ze słowami takimi, jak np. poezja, żotnierz, państwo, z wieloma nazwami zwierząt, miejscowości, kierunków myślowych itp. Dla części z tych nazw, a także wyrazów, które traktujemy jako niewątpliwe elementy języka wartości w danej kulturze, badania statystyczne moga wykazać wysoki procent jakiegoś nacechowania wartościującego, ale zazwyczaj nie będzie ono dotyczyć wszystkich użyć ani też obejmować wszystkich badanych. Te n nale żą cy do pragmatyki rodzaj odmienności, ujawniający się w kontaktach językowych, może powodować spory, niechęci, poczucie obcości, czasem téz tendencje do ośmieszania inaczej myślacego i ocen i a ja c e g o ${ }^{1}$ [Puzynina 2014, 8].

Użytkownicy języka, jak pokazuje praktyka korespondencyjna poradni językowych, ale również wielość sytuacji, w której językoznawcy występują w roli biegłych sądowych w sprawach o zniesławienie, maja kłopot $z$ jednoznacznym rozpoznaniem, czy mamy do czynienia $z$ obraźliwym, pogardliwym odezwaniem się do kogoś bądź o kimś. I problem ten dotyka nawet najbardziej świadomych spośród nich. Jadwiga Puzynina [Puzynina 2016] wspomina na przykład różnice w odniesieniu do rzeczownika świr, które w pragmatycznej ocenie dziela ją i Andrzeja Bogusławskiego. A. Bogusławski uważa, że świr w każdym użyciu jest słowem obraźliwym. J. Puzynina $z$ kolei jest zdania, że tego określenia można

${ }^{1}$ Wyróżnienia w tekście - D.Z.J. 
użyć w pewnych sytuacjach żartobliwie: „oj ty świrze”. Wartościowanie w tym słowie zależy od różnych czynników - tematu, którego wypowiedź dotyczy, kontekstu wypowiedzi, stosunku tego, kto mówi, do tego, o kim lub do kogo się mówi, także od intonacji, od towarzyszących gestów itd. J. Puzynina w tym samym wywiadzie podkreśla:

Zwłaszcza wartościowania dotyczace nazw ludzi, przedmiotów, zdarzeń, odbieramy bardzo różnie. Czasem to różne rozumienie słów w poszczególnych użyciach wiąże się $z$ bardzo ogólnym ich znaczeniem. Przykładem może tu być przymiotnik dobry. $Z$ bliska mi profesor Renatą Grzegorczykową inaczej rozumiemy słowo dobroć. Obie wywodzimy się $z$ warstwy inteligenckiej, obie należymy do środowiska akademickiego, A tymczasem dla mnie dobroć wiąże się $z$ postawa, tj. ze stosunkiem do innego człowieka, a także $z$ chęcia pomocy czynnej temu, kto tego potrzebuje. Nieodzowne jest to poczucie potrzeby pomocy, jeśli już nie jakieś czynne działanie. Natomiast profesor Grzegorczykowa uważa, że wystarczy, jeżeli umiemy sobie wyobrazić, na czym polega czyjeś nieszczęście; działanie, nawet chęć działania, nie sa konieczne. W naszej dyskusji, opisanej w jednym $z$ moich artykułów, ona kładzie duży nacisk właśnie na wyobraźnię i dalej warszawska językoznawczyni podkreśla: „Co ważne w tej całej sprawie braku jednorodności w rozumieniu słów? To że różnice dotyczą szczególnie często wyrazów (i wyrażeń) nacechowanych aksjologicznie. Uwidoczniają to przytoczone wyżej przykłady. Może to dotyczyć całych grup użytkowników języka. Proszę wziaćc pod uwagę, powiedzmy słowa uczciwy i uczciwość. Jedni uważaja, że mamy tu do czynienia $z$ bezwzględna zasada, że nie ma sytuacji, w której można być nieuczciwym, na przykład kraść. Sa jednak tacy, którzy nie uznaja za nieuczciwość tego, że ktoś głodny kradnie bułkę w piekarni. Ale znowu, co do tych usprawiedliwiających okoliczności zdania są bardzo podzielone. Mówi się o białym kłamstwie, na przykład, wobec kogoś śmiertelnie chorego, przed kim zatajamy jego stan. Sa jednak tacy, którzy kategorycznie negują białe kłamstwo, twierdzac, że przysporzenie cierpienia nieuleczalnie choremu jest mniejszym złem niż powiedzenie mu nieprawdy. Sa tacy lekarze, sa tacy księża [Puzynina 2016].

\section{SPOSÓB WPROWADZANIA INFORMACJI PRAGMATYCZNEJ W SLOWNIKU POPRAWNOŚCIOWYM}

Osobną kwestię natury metodologicznej stanowi sposób wprowadzania informacji pragmatycznej w słowniku poprawnościowym. Tradycyjnie do tego celu służą w hasłach słownikowych, także w słowniku ortoepicznym, szczegółowe kwalifikatory. Te pozwalają na kondensację opisu właściwości pragmatycznych. Czasem jednak zastosowania kwalifikatora nie można uznać za wystarczające pokazanie okoliczności, w jakich użycie jednostki języka ma takie, a nie inne konsekwencje komunikacyjne, np. obraża czy deprecjonuje. Wydaje się, że czasem, by słownik ortoepiczny rzeczywiście spełniał swoją funkcję, okoliczności takie winny być przedstawione w sposób bardziej opisowy, narracyjny, nie da się ich bowiem zamknąć tylko w systemie kwalifikatorów. 


\subsection{Kwalifikatory pragmatyczne}

Jako wystarczajace byłoby może zamykanie informacji pragmatycznej w stosownym kwalifikatorze, np. w odniesieniu do takich wyrazów niebezpiecznych w przestrzeni publicznej (niepoż.?), które w odczuciu wszystkich albo części użytkowników języka deprecjonują, dyskryminują ludzi ze względu na ich tożsamość: narodowość (por. pejsol, parch), rasę (np. ciapaty, banan, kokos, oreo 'o osobach czarnoskórych'), religię (np. katol), płeć (por. słaba płeć, kura domowa 'o kobietach'), orientację seksualna (np. homoś, pedał) itd. albo określaja negatywne cechy wyglądu, umysłu itp. człowieka, także jego poglądy w sposób może nawet i prawdziwy, ale nieprzyjemny (np. kurdupel, głupek, debil, palant, platfus 'członek Platformy Obywatelskiej', pisior 'zwolennik albo członek partii PIS', moher 'osoba starsza, zwłaszcza kobieta o konserwatywnych poglądach'), dotycza pewnych nieprzyjaznych sposobów mówienia o ludzkich ułomnościach, na które nie mają wpływu, np. o ich chorobach (por. kaleka, upośledzony umysłowo, niedorozwinięty, opóźniony $w$ rozwoju). Podobne wyrazy funkcjonuja często w mowie potocznej i przez fakt, że są nośnikami krzywdzących stereotypów nie służą kształtowaniu dobrych relacji między ludźmi, a więc nie sprzyjają dobrej, prowadzącej do porozumienia komunikacji językowej. Słownik ortoepiczny, mający za zadanie dostarczenie wzorców więcej niż tylko p o p ra w n e g o, a więc wła ś ciwe go zachowania językowego, i kodyfikujący normy obyczajowe w zakresie użycia języka, powinien dziś przestrzegać przed konsekwencjami komunikacyjnymi i społecznymi posługiwania się $\mathrm{w}$ sferze publicznej wyrażeniami odczuwanymi (choćby tylko przez część użytkowników) jako obraźliwe czy wzbudzające niechęć wobec jakiejś osoby (lub grupy osób) ze względu na jej tożsamość, w celu jej społecznego wykluczenia albo jako sygnał braku życzliwości wobec osób odmiennych „Z natury” lub „Z własnego wyboru” (słuchających odmiennej niż inni muzyki, ubierających się inaczej czy majacych nietypowe lub tylko inne niż mówiący poglądy).

\subsection{Artykuły narracyjne (opisowe) związane $z$ wybranymi leksemami - exemplum: pan / pani}

Sa jednak jednostki leksykalne, których właściwości pragmatyczne sa tak złożone, że ich omówienie w słowniku wymagałoby jednak bardziej rozbudowanego komentarza, a nie tylko opatrzenia ich kwalifikatorem pragmatycznym. Jako przykład takich jednostek i należnych im komentarzy mogłyby posłużyć jednostki pan / pani.

Zwróćmy uwagę, że właściwe posługiwanie się rzeczownikami pan / pani wymaga od użytkowników języka wielu kompetencji natury pragmatycznej. Ważna ich funkcją w polszczyźnie jest komunikowanie honoryfikatywnego nacechowania rzeczownika, obok którego wyrazy 
te występują. Rzeczownikiem takim może być nazwa antroponimiczna (imię - w formie pełnej lub zdrobniałej, nazwisko, imię połaczone $z$ nazwiskiem) czy też rzeczownik tytularny (np. doktor, profesor, prokurator, prezydent).

Struktury „pan / pani + nazwa antroponimiczna lub rzeczownik tytularny" użyte nie w sposób adresatywny (tzn. nie podczas zwracania się do danej osoby), lecz referujący, narracyjny (gdy mówimy o kimś trzecim) maja zasięg ograniczony do pewnych okoliczności, stosowane sa np. $\mathrm{w}$ adresowaniu korespondencji czy podczas publicznej prezentacji nazwisk $z$ listy [por. Huszcza 2006, 113]. W innych okolicznościach w tekstach ściśle narracyjnych, jeżeli między nadawca a osobowym obiektem narracji nie zachodzi społeczna relacja jakiejś bliższej znajomości, nie poprzedza się rzeczowników tytularnych lub antroponimicznych wyrazem pan / pani [por. Huszcza 2006, 110-115; Łaziński 2006, 15]. Połączenie takie (pan prezydent, pan profesor) nadaje się tylko na okoliczności bardzo uroczyste, a także w sytuacjach, w których przemawiamy w obecności tych osób (prezydenta, profesora) i chcemy okazać im szczególny szacunek.

W miejscu pracy - w relacjach oficjalnych formuła wyrażajacca szacunek jest połączenie „pan / pani plus nazwa stanowiska lub stopień naukowy", np.: panie profesorze, pani dyrektor, panie kierowniku, pani prezes. Zwykle jednak pomija się tę część tytułu zawodowego, który obniża rangę rozmówcy. Do zastępcy dyrektora zwracamy się zatem panie dyrektorze, a do wiceministra - panie ministrze. Także o osobach, a zwłaszcza do osób, które w przeszłości pełniły ważne funkcje państwowe (np. funkcje premiera, prezydenta), zwyczajowo mówimy panie premierze (premier Mazowiecki), panie prezydencie (prezydent Kwaśniewski).

W niektórych środowiskach zawodowych, np. akademickim czy lekarskim, żywy jest w formułach adresatywnych zwyczaj skracania dystansu przez redukcje form typu panie profesorze, panie doktorze - do członu profesorze, doktorze (dotyczy to jednak wyłącznie zwracania się do mężczyzn).

Jednostki leksykalne pan / pani silnie kojarzone sa $z$ podstawowym celem grzeczności językowej, czyli wyrażaniem szacunku wobec drugiej osoby. W sytuacji „referującej” moga one jednak być oznaka złamania zasad etykiety - znakiem lekceważenia, a czasem - ironii [por. Łaziński 2006, 84]. I tak np., gdy mówi się o osobie znanej, poprzedzając jej nazwisko lub imię wyrazem pan / pani (np. pan Duda, pan Wałęsa, pan Stefan zamiast Stefan Niesiołowski) - podobny zabieg służy deprecjacji tej osoby. Lekceważenie, wyrażanie dystansu, ironii lub nawet poniżanie osób znanych za pomoca dodawania do antroponimów wyrazów pan / pani spotykane jest przede wszystkim w dyskursie publicznym, medialnym. Podobnie jest w wypadku „referujących” użyć rzeczowników pan / pani przed nazwiskiem takiego znanego polityka lub artysty, któremu tytuł nie przysługuje (np. pani Pawłowicz, pani Żmuda-Trzebiatowska), 
także twórcy jakiegoś znanego dzieła literackiego, malarskiego, filmowego itp. (np. obrazy pana Matejki, filmy pana Wajdy, wiersze pani Szymborskiej) lub w sytuacji, gdy rzeczowniki pan / pani sa użyte zamiast adekwatnych wobec osób duchownych rzeczowników ksiądz czy siostra. Jako lekceważące odczuwane jest również dodanie wyrazu pan / pani do nazwiska lub imienia autora tekstu w polemicznych wobec niego recenzjach [por. Łaziński 2006, 89-90], np. rozprawa pani Kowalskiej.

Rzeczowniki pan / pani łączą się z czasownikiem w 3. osobie 1. pojedynczej. Odstępstwa od tej reguły - np. Gdzie sie pan pchasz? - nie mieszczą się regułach grzeczności językowej.

Formuły ten pan / ta pani mogą być używane w prywatnej rozmowie, np. do dziecka: Nie mów tak, bo sprawisz tej pa ni przykrość. Mówienie jednak w taki sposób o kimś publicznie jest oznaka braku szacunku (por. wypowiedź ministra Ziobry o znanym profesorze medycyny: Już nikt nigdy przez tego pana życia pozbawiony nie będzie, posłanki Pawłowicz o innej posłance: ta pani).

Zwracanie się w relacjach prywatnych i zawodowych za pomoca formy panie lub pani poprzedzającej tylko nazwisko (np. panie Kowalski, pani Kowalska) zwykle nie jest przez użytkowników dobrze widziane, choć jest akceptowalne w środowiskach małych miejscowości, gdzie wszyscy się znaja.

W młodszym pokoleniu użytkowników języka upowszechnia się łączenie rzeczowników pan / pani z imionami (także zdrobniałymi): pani Ania, pan Wojtek, nawet w bezpośrednich zwrotach, i to do osób starszych i hierarchicznie wyższych lub nawet w kontakcie oficjalnym (pani Aniu, panie Wojtku), co więcej - bez obustronnego uzgodnienia (np. zwraca się tak student w korespondencji mejlowej do nauczyciela akademickiego). Taki sposób zwracania się przez krzewicieli stosunkowo nowego zwyczaju odczuwany jest przez jego zwolenników jako pozytywna oznaka sympatii. Coraz częściej omawiana formuła staje się także częścia „grzeczności handlowej". Zwracaja się tak do klientów pracownicy banków, agenci ubezpieczeniowi czy akwizytorzy. W tych okolicznościach funkcja pragmatyczna takiej formuly jest spersonalizowanie i ocieplenie kontaktu. Dla użytkowników przywiązanych do tradycji taka forma jest odczuwana jako poufała, akceptowana więc tylko wobec kogoś, z kim łączą nas rzeczywiście bliskie stosunki towarzyskie (nie na tyle jednak symetryczne, byśmy mogli „przejść na ty”), a nie w rozmowie $z$ osoba stojąca w hierarchii wyżej, np. $z$ przełożonym lub $z$ osobą znacznie starszą. Wśród tych użytkowników języka omawiana forma preferowana jest tylko w osobowych relacjach symetrycznych - stosowana przez obie strony interakcji i za zgodą obu rozmówców. Może być ewentualnie stosowana przez jednego $z$ nich, ale tylko starszego lub wyższego ranga w hierarchii społecznej czy zawodowej wobec osoby młodszej lub zajmujaccej niższą pozycję hierarchiczna - forma wyraża wtedy życzliwość i sympatię, ale również może stanowić sygnał asymetrii statusu partnerów. Dlatego dobrze w po- 
dobnych okolicznościach posługiwać się taka forma $z$ wyczuciem, by jedna ze stron interakcji nie czuła się dyskryminowana ze względu na wiek czy status. To bowiem, co w naszej intencji miało być sygnałem sympatii, może zostać zinterpretowane jako protekcjonalizm, traktowanie rozmówcy $z$ wyższością.

W sytuacjach codziennych ze słowami pan / pani Polacy używają czasem nazwy zawodu jako tytułu (np. panie kierowco, panie dozorco). Zwyczaj ten, choć powszechny, nie przez wszystkich użytkowników języka jest akceptowany. Podkreślanie w ten sposób niskiej funkcji zawodowej rozmówcy nie jest odbierane jako taktowne.

W warunkach pisemnej komunikacji oficjalnej (w mejlach, ankietach, ulotkach), gdy nie znamy płci odbiorcy, możemy zastosować 4 konwencje adresatywne, każda ma jednak swoje ograniczenia:

- zastosować ukośnik Pan / Pani;

- formę adresatywna żeńska lub jej fleksyjny wykładnik podać w nawiasie: Pan (Pani) lub Pan(i);

- użyć adresatywu Państwo;

- użyć form czasownikowych 2. os. 1. poj. łączących się zwykle z zaimkami ty, twój.

Wielość ukośników lub nawiasów w tekście nie jest wygodna (ekonomiczna) i nie wygląda najlepiej, por.: Szanowny Panie (Szanowna Pani), przesyłam Panu (Pani) nasza oferte sprzedaży zestawów fotowoltaicznych. Jeśli zainteresował Pana (Pania) prad ze słońca, doradzimy Panu (Pani) w wyborze urzadzeń i miejsca montażu.

Rozwiąanie nawiasowo-ukośnikowe ma również inny mankament - nie pozwala uwolnić się od „uwikłania w płeć” (a tę w interesującym nas kontekście chcielibyśmy właśnie „obejść”), ponadto kolejność wyrazów (najpierw forma pan, później pani) może być przez niektórych użytkowników języka (np. środowiska feministyczne) postrzegana jako dyskryminujaca kobiety. Pewnym rozwiązaniem jest zatem w takiej sytuacji zastosowanie formy Państwo, która - choć zasadniczo odnosi się do kilku osób obojga płci (przynajmniej dwojga) - w sytuacji odbioru konkretnej wypowiedzi może jednak odnosić się do adresata jednostkowego: Szanowni Państwo, przesyłam nasza oferte sprzedaży zestawów fotowoltaicznych. Jeśli zainteresował Państwa prad ze słońca, doradzimy Państwu $w$ wyborze urzadzeń $i$ miejsca montażu, a także wykonamy kalkulacje kosztów instalacji.

W niektórych okolicznościach (np. w przepisach kulinarnych, poleceniach i pytaniach egzaminacyjnych, podręcznikowych i ankietowych czy w ulotkach informacyjnych) bardziej naturalna będzie forma ty połączona $z$ 2. osoba czasownika lub (czasami) - bezosobowa, np.: Rozpuść sól $w$ szklance wody (Proszę rozpuścić sól $w$ szklance wody), W podanym zdaniu znajdź 3 rzeczowniki ( $W$ podanym zdaniu prosze znaleźć 3 rzeczowniki), lle godzin dziennie poświęcasz na przegladanie Internetu? Pewną ostrożność trzeba zachować, zastępując formę pan / pani formą 
ty w pisanych tekstach ofert (np. handlowych czy bankowych). Zmniejszenie za jej pomoca dystansu, kształtowanie bardziej partnerskiej relacji nie zawsze jest akceptowane przez starszych użytkowników języka.

Forma adresatywna pośrednią między pan / pani a ty sa połaczenie imienia - świadczacego o relacji na ty - ze zdaniem, w którym relacja między nadawca a odbiorca określona jest na pan / pani (np. Joasiu, czy może Pani podać nam przykład). Takie połaczenia maja charakter protekcjonalny albo służą skróceniu dystansu. Tak zwykle mówi ktoś wyższy ranga (np. wiekiem lub stanowiskiem) do kogoś młodego, np. profesor uczelni do studenta. W takich okolicznościach spotyka się to na ogół $z$ aprobatą.

\subsection{Artykuły opisowe związane $z$ kategoriami wyrazów (exempla: wyrazy dziecięce, metaforyczne nazwy osób)}

Wydaje się, że pragmatyczny aspekt normy językowej może być ujmowany w słowniku właściwych użyć języka nie tylko w „zakładkach pragmatycznych" haseł szczegółowych, ale także zostać ujęty kompleksowo jako hasło „teoretyczne” odnoszace się albo do właściwości pragmatycznych pewnych kategorii słów (jak np. deminutiwa, słownictwo dziecięce, metafory odnoszace się do osób).

Przyjrzyjmy się pod tym katem na przykład tzw. wyrazom dziecięcym. Wyrazy dziecięce to słowa w rodzaju: am, lulu, hajty, ała, myju, mniam, mniam, kaku itp. Składaja się one na tzw. język nianiek - język zwłaszcza kobiet, w mniejszym stopniu - mężczyzn, służący dorosłym budowaniu więzi z dzieckiem za pomoca słowa. Słownictwo tego rodzaju stanowi część rejestru leksyki ekspresywnej w ramach języka familijnego, ten zaś należy do stylu potocznego. Zdarza się wszakże, że niektóre wyrazy języka nianiek używane sa także między dorosłymi użytkownikami języka, jednak tylko w sytuacji nieoficjalnej i gdy rozmówców łączą bardzo bliskie więzi (np. słowo siusiu). Posługiwanie się nimi w sytuacji oficjalnej i wobec osób obcych, starszych (wiekowych), np. w domach seniorów lub wobec osób publicznie znanych, ma charakter deprecjatywny, ośmieszajacy, nie jest grzeczne. Jako taka może być zinterpretowana wypowiedź posłanki podczas posiedzenia parlamentu do innych posłów: tak smakuje opozycja, m n ia $m, m$ n ia $m$. Trzeba to jasno podkreślić, że posługiwanie się wyrazami dziecięcymi w sytuacji oficjalnej i wobec osób publicznych lub w odniesieniu do nich ma funkcję ośmieszająca, deprecjatywna, a nawet obraźliwą, o czym świadczy fragment pamiętnego felietonu $z$ tygodnika „Nie”, w którym autor o Janie Pawle II pisał, zwracajacc się do niego bezpośrednio:

Kochany staruszku! Połóż się do łóżka. Przykryj kołderką. Poczytaj sobie Katarzynę Grocholę albo jakiś lekki kryminał. Poćpaj kawiorku, pocmoktaj melbę, m n i a m, m n i a m. Puść se na wideo „Dzień świra” - uśmiejesz się zacnie. Podłub sobie w nosie 
albo między palcami u nóg, co tam lubisz. Trochę drzemki, potem kak u [J. Urban, Obwoźne sado-maso, „Nie” nr 33/2002].

Za inny przykład kategorii słów, które mogłyby zasługiwać na kompleksowy opis pragmatyczny w kontekście słownika użyć właściwych niech posłuża metafory nazywające osoby. Opisując innych ludzi ze względu na ich wygląd, cechy charakteru, poglądy itp., by oddać je w sposób bardziej obrazowy, korzystamy $z$ metafor, zarówno tych konwencjonalnych, utrwalonych w przenośnych znaczeniach wyrazów (np. mrówka - 'o kimś pracowitym'), jak i tworzonych indywidualne, innowacyjnie (np. bulterierka PIS-u).

Duża grupa metafor obu typów ma charakter deprecjonujący, a nawet obraźliwy. Należą do nich na przykład takie utrwalone w języku przenośnie, które oparte sa na rzeczownikach w znaczeniach dosłownych odnoszacych się do zwierząt niższego rzędu, zwłaszcza mięczaków, płazów, gadów, robaków, ryb itp.: truteń, gnida, menda, pijawka, rekin, płotka, ropucha, żmija, mięczak, wą̇̇, kameleon. Ogólnie posługiwanie się przenośnymi nazwami zwierząt w odniesieniu do ludzi wymaga wielkiej ostrożności, duża część $z$ nich ufundowana jest na negatywnych stereotypach, jakie przypisujemy w naszej kulturze wielu zwierzętom (np. głupotę - gęsi, złośliwość - małpie, hienie - agresywność) itp. Stąd posługiwanie się w odniesieniu do ludzi rzeczownikami gęś, małpa, hiena itp. może być odbierane jak inwektywa skierowana wobec tych osób. Podobnie funkcję deprecjatywna spełniają rzeczowniki pierwotnie odnoszące się do części ciała zwierząt (np. pysk, morda, łapa, kopyto) lub czynności przez nie wykonywanych albo też stanów, którym podlegaja, np. zdychać, żreć. Wszystkie wymienione i podobne im słowa, gdy używamy ich w odniesieniu do człowieka, deprecjonuja jego godność przez swego rodzaju animalizację (nadanie człowiekowi cech zwierzęcych).

Sytuacja jest analogiczna, jeśli sięgamy po metafory tworzone okazjonalnie, ale $z$ wykorzystaniem mechanizmu, o którym była mowa, por.: On jest $z$ pierwszego zawodu entomologiem, profesorem owadologii $i$ jego naturalne środowisko ekologiczne to wszy, mendy, gnidy, pluskwy, muchy plujki, żuki gnojniki i to jest również jego elekto rat. I to świadczy o potędze polskiej demokracji, nawet wszy, mendy maja swoja reprezentacje [J. Pietrzak, koncert 21 marca 2016 r.].

$Z$ kolei nazwy przedmiotów użyte metaforycznie do nazwania człowieka, por.: traba, cymbat, drewniak, młotek, moher, dzban itp., w jakimś stopniu reifikuja go (uprzedmiotawiaja) i dlatego sa przez użytkowników języka także odbierane jako deprecjonujące tak nazywane osoby.

Do metafor ludzkich niepożądanych w dialogu, w którym zależy nam na porozumieniu w klimacie szacunku, należą również przenośnie oparte na nazwach zawodów w naszej tradycji kulturowej nisko cenionych, takich jak: zawody ośmieszające (np. kuglarz, komik, komediant, magik, klaun), polegajace na przesadnym dozorowaniu (np. ekonom, żandarm, 
kapral, zomo) czy związane $z$ pozbawianiem życia ludzi lub zwierzat (np. hycel, rzeźnik, kat, oprawca).

\section{Bibliografia}

J.D. Apresjan, 1974, Leksicheskaia semantika. Sinonimicheskie sredstva iazyka, Moskwa; tłum. pol. Z. Kozłowska, A. Markowski, 2000, Semantyka leksykalna. Synonimiczne środki języka, Warszawa.

J.D. Apresjan, 1988, Informacja pragmatyczna $w$ słowniku jednojęzycznym [w:] Z. Zaron (red.), 2012, Z warsztatu leksykografa, Warszawa, s. 41-63; pierwodruk w: Прагматика и проблемы интенсиональности, Moskwa, s. 7-44.

M. Bańko, 2008, O normie i błędzie, „Poradnik Językowy” z. 5, s. 3-17.

A. Bogusławski, 1973, Właściwości pragmatyczne wyrażeń równoznacznych. Projekt schematu, „Pamiętnik Literacki” z. 3, s. 121-151.

A. Bogusławski, M. Danielewiczowa, 2005, Verba polona abscondita. Sonda słownikowa III, Warszawa.

A. Bogusławski, T. Garnysz-Kozłowska, 1979, Addendum to Polish phraseology. Introductory issue. Addenda do polskiej frazeologii. Zeszyt wstęny, Edmonton.

A. Bogusławski, J. Wawrzyńczyk, 1993, Polszczyzna, jaka znamy. Nowa sonda słownikowa, Warszawa.

W. Doroszewski (red.), 1976, Słownik poprawnej polszczyzny, Warszawa.

G. Gazdar, 1979, Pragmatics: Implicature, Presupposition, and Logical Form, New York.

R. Huszcza, 2006, Honoryfikatywność-gramatyka, pragmatyka, typologia, Warszawa.

R. Kalisz, 1993, Pragmatyka językowa, Gdańsk.

M. Łaziński, 2006, O panach i paniach. Polskie rzeczowniki tytularne i ich asymetria rodzajowo-płciowa, Warszawa.

A. Markowski (red.), 2018, Wielki słownik poprawnej polszczyzny, Warszawa.

A. Markowski, J. Puzynina, 1993, Kultura języka [w:] J. Bartmiński (red.), Wspótczesny język polski, Wrocław, s. 53-72.

R. Montague, (1968) 1974, Pragmatics [w:] R.H. Thomason (red.), Formal Philosophy. Selected Papers of Richard Montague, New Haven, s. 95-118.

Ch. Morris, 1938, Foundations of the theory of sings [w:] O. Neurath, R. Carnap, Ch. Morris (red.), International Encyclopaedia of United Science I, Chicago, s. 1-59.

J. Puzynina, 2014, Kłopoty z nazwami wartości (i wartościami), „Etnolingwistyka" nr 26, s. 7-20.

J. Puzynina, 2016, Zawsze rozmawiać, https://teologiapolityczna.pl/zawszerozmawiac-przeczytaj-wywiad-z-prof-jadwiga-puzynina [dostęp: 12.12.2019].

P. Stalmaszczyk, 2008, Semantyka formalna i pragmatyka: przeglad wybranych definicji, „Biuletyn Polskiego Towarzystwa Językoznawczego” LXIV, s. 9-24.

R.C. Stalnaker, 1970, Pragmatics, „Synthese” 22, s. 272-289.

R.C. Stalnaker, 1972, Pragmatics [w:] G. Harman, D. Davidson (red.), Semantics of Natural Language, Dordrecht, s. 380-397.

S. Szober, 1937, Słownik ortoepiczny: jak mówić i pisać po polsku, Warszawa.

S. Szober, 1948, Słownik poprawnej polszczyzny, Warszawa. 


\section{Pragmatic information in an orthoepic dictionary. Current state and needs}

\section{Summary}

For language users, language is a certain continuum along which the boundary between semantics and pragmatics blurs and where phenomena from both planes are related to the concept of language norm (linguistic standard, literary norm) and the proper use of linguistic units is not limited to complying with the rules of grammar or respecting their strict meaning. An important component of the proper use of language is the pragmatically adequate selection of the available language means. The question of a methodological nature is the way in which pragmatic information is introduced to such lexicons. Traditionally, usage labels are used for this purpose. Sometimes, however, in order for an orthoepic dictionary to really fulfil its function, pragmatic information should be presented in a more descriptive, narrative manner. The pragmatic aspect of the language norm can be described in a dictionary not only in the "pragmatic tabs" of specific entries but it can also be captured comprehensively, as a "theoretical article" relating either to the pragmatic properties of certain word categories (e.g. diminutives, children's vocabulary, metaphors relating to people).

Keywords: pragmatics - orthoepic dictionary - language norm - correctness.

Adj. Monika Czarnecka 